\title{
Ergonomic and organizational analysis of an association of collectors of recyclable waste
}

\author{
Maria, $\mathrm{R}^{\mathrm{a}}$; Chagas, $\mathrm{T}^{\mathrm{b}}$ and Silva $\mathrm{V}^{\mathrm{c}}$ \\ ${ }^{a}$ Professor at Federal Institute of Education, Science and Technology of Minas Gerais - 3007, Michael Pereira de \\ Souza Avenue - Campinho - Congonhas - MG - Brazil-Zip Code: 36.415-000; e-mail: robert.maria@ifmg.edu.br \\ ${ }^{b}$ Professor at Federal University of Ouro Preto. School of Minas - Morro do Cruzeiro Campus - Ouro Preto - \\ MG - Brazil - Zip Code: 35.400-000; e-mail: tays_torres@yahoo.com.br \\ ${ }^{c}$ Professor at Centro Universitário de Patos de Minas - 808, Major Gote Street - Caiçaras - Patos de Minas - MG \\ - Brazil - Zip Code 38.702-054; e-mail: vivianne@unipam.edu.br
}

\begin{abstract}
The managerial difficulties encountered by an Association of Recyclable Materials Collectors to organize and ensure the perpetuation of his work gave rise to this research. In order to overcome the difficulties encountered with regard to accounting, organizational and ergonomic work, we used a methodology capable of providing a greater interaction between researchers and collectors, facilitating the exchange of knowledge and the perpetuation of the techniques used. Improvements were seen in relation to screening, storage and organization of work.
\end{abstract}

Keywords: participation; solidarity economy; labor; income

\section{Introduction}

This paper arose from the observation of the difficulties encountered in management associations and/or cooperatives of recyclable material collectors. After a brief search in the city, the Association of Recyclable Material Collectors of the Rancharia - ACMAR- was found, in the city of Ouro Preto.

ACMAR was founded in March 2006 by the municipal government with the purpose of removing workers from poor working conditions in the city's rubbish dump. The city hall is responsible for renting the warehouse, in which all the material collected is unloaded. In this warehouse, the collectors, separate, weigh and pack the material in bags, which will be sold to middlemen or directly to factories or businesses.

The equipments in the warehouse - press, baler, scales, hydraulic lift, paper shredder and tubular cart - were donated by the municipal government, which is responsible for their maintenance. As to the transportation of materials - collecting and selling - the city provides trucks and drivers. In addition, the warehouse is equipped with an office, kitchen and restroom for the collective use of the collectors.

A diagnosis of the local as well as the application of ergonomic tools and management of Industrial Engineering was held as to provide the workers with better working conditions and enable them to selfmanage the collection, selling and accounting of the project.

\section{Methodology}

Work methodology consisted of the steps listed below:

- Survey literature on the Solidarity Economy and the recycling of materials;

- Selection of Industrial Engineering tools to be used;

- Field research in order to get to know the local diversity;

- Regular meetings with the collectors to adapt the work plan to their reality; 
- Training actions for the collectors: in workplace safety, production planning tools: 5S, PDCA cycle and costs.

\section{Results and discussions}

The work made it possible to raise awareness and incorporate the importance of selective collection of disposals in the local community and the academic community both. There were improvements in the logistics of collecting the materials, in the time of execution and in the frequency of collecting in certain places. There was significant improvement in the process of measuring the weight of the collected products and therefore in the knowledge of their market value, contributing to the improvement in regard to income generation.

Regarding the collection, sorting, storage of recyclable materials, the measurement of the pressed bags, the accounting aspects and the organization of work (work shifts, hours of operation, activities, division of labor, hygiene of the workplace, and definition and planning of collection routes), we observed significant improvements by conducting training courses: 5S, daily PDCA of the warehouse activities, cost management and study and improvement of collection routes.

In addition, we observed improvements in working conditions with regard to problems related to ergonomics and worker safety through awareness and use of personal protective equipment (PPE) and relocation and rotation of activities, avoiding fatigue and diseases related to posture.

\section{Conclusion}

The advantages of recycling the waste go beyond reducing the environmental impacts, the selective collection held in urban areas, if done properly, can generate income to a segregated part of the population of the formal labor market, thus benefiting many families.

The study of organizational factors and working conditions of ACMAR provided relevant information to propose and implement improvements in the working conditions of members, it has also shown the difficulties encountered by collectors of recyclable materials. We show the importance of allocating them in a field of self-management action within the principles of the Solidarity Economy, so that through the work of the organization and coordination, they can raise their living conditions and act socially as collaborators in the process of enhancement of sustainable development, at least locally, in their county or circle of action. In this process, the partnership of government and civil society collaboration is very important.

\section{References}

[1] Antunes, R., Alves, G. As Mutações no mundo do trabalho na era da mundialização do capital. Educ. Soc., Campinas, vol. 25, n.87, p.335-351, mai/ago, 2004. In: http://www.cedes. unicamp.br. Acesso em 20/06/2011.

[2] Conceição, M. M.; Empresários do Lixo: um paradoxo da modernidade: análise interdisciplinar das Cooperativas de reciclagem de lixo. Campinas, SP. $2^{\text {a }}$ edição. Editora Átomo, 2005.

[3] Iida, I. Ergonomia: Projeto e Produção.2a edição. São Paulo: Editora Edgard Blucher, 2005.

[4] IPT. Instituto de Pesquisas Tecnológicas. O Lixo: Manual de gerenciamento integrado. $2^{\mathrm{a}}$ edição. São Paulo: IPT, 2000.

[5] Wisner, A. Por dentro do trabalho.Ergonomia: método \& técnica. São Paulo: FTD/Oboré, 1987. 